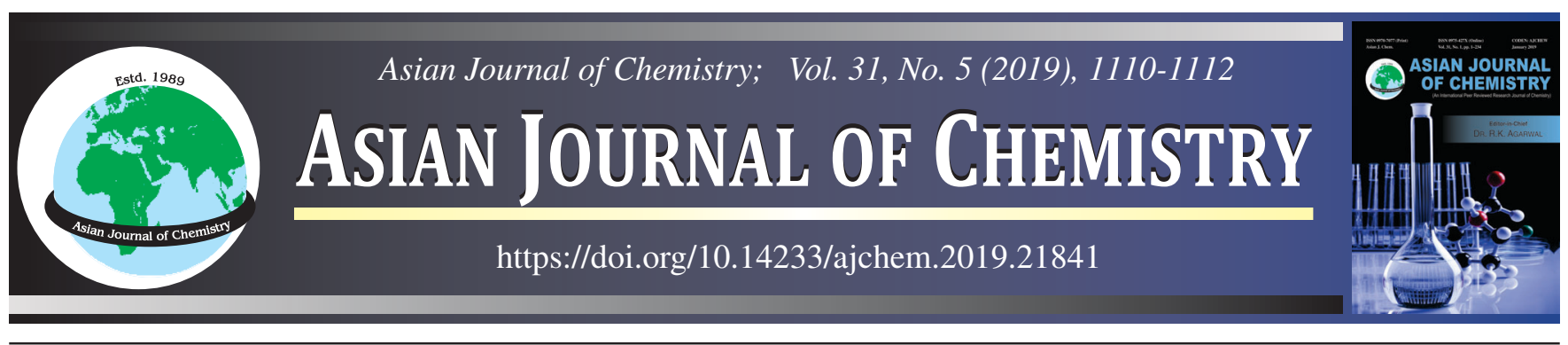

\title{
Chemical Composition and Acetylcholinesterase Inhibition Activity of Volatile Oil from Leaves of Arbutus unedo L. from Croatia
}

\author{
O. Politeo*®• and I. ERCEGovic
}

Faculty of Chemistry and Technology, University of Split, Split, Croatia

*Corresponding author: Fax: +385 21 329461; Tel: +385 21 329437; E-mail: olivera@ktf-split.hr

Received: 26 November 2018;

Accepted: 17 January 2019;

Published online: 28 March 2019;

AJC-19340

The volatile oil from leaves of Arbutus unedo L. from Croatia was subjected to chemical composition and acetylcholinesterase inhibition activity. The tested volatile oil was dominated by nonterpene compounds, with $(E)$-2-decenal, nonanal, nonanoic acid and octanol as main compounds. Terpene compounds were identified in lower quantity, with linalool and $\alpha$-terpineol as main ones. Results showed low to moderate acetylcholinesterase (AChE) inhibition potential of tested oil, for tested concentration of $1 \mathrm{mg} / \mathrm{mL}$.

Keywords: Arbutus unedo L., Volatile oil, GC-MS, Ellman.

ᄂ _ - - - - - - - - - - - - - - - - - - - - - - - - - - - -

\section{INTRODUCTION}

The genus Arbutus belonging to Ericaceae family. Arbutus unedo L., commonly known as strawberry-tree, is an evergreen shrub or small tree, native in the Mediterranien region. Almost all parts of the $A$. unedo plant (leaves, fruits, bark, roots and honey) have been used in traditional medicine for the treatment of many different diseases. Many ethnobotanical studies confirmed biological potential of $A$. unedo extracts in the treatment of kidney, gastrointestinal, dermatologic, urological, cardiovascular and hypertensive diseases and diabetes $[1,2]$. The medicinal characteristics of this plant is related to pharmacologically active compounds which are present in different parts of plant. A lot of study has been performed about phytochemical composition of different parts of Arbutus unedo. Among them, only two studies have been performed regarding chemical composition of volatile oil from leaves of $A$. unedo $[3,4]$.

The aim of this work was to determinate the chemical composition as well as acetylcholinesterase inhibition activity of volatile oil from leaves of Croatian Arbutus unedo. To our best of knowledge this is the first report about chemical composition of volatile oil from leaves of Arbutus unedo from Croatia as well as the first record about acetylcholinesterase (AChE) inhibition activity of this volatile oil.

\section{EXPERIMENTAL}

Plant material (fresh leaves) was collected in October 2015 near Split, Croatia. Plant material was identified by a botanist dr. Mirko Ruscic, associate professor, Department of Biology, Faculty of Science, Split, Croatia. A voucher specimen of plant material was deposited in herbarium at the Department of Biochemistry, Faculty of Chemistry and Technology, Split, Croatia.

Volatile oils isolation: The fresh leaves of Arbutus unedo L. were subjected to hydrodistillation using a Clevenger-type apparatus for $3 \mathrm{~h}$. The obtained volatile oils were stored in a sealed vial, under $-20{ }^{\circ} \mathrm{C}$ until use.

Gas chromatography (GC) and gas chromatographymass spectrometry (GC-MS) analyses: GC and GC-MS analyses of isolated volatile oils were performed using Agilent Technologies (Palo Alto, CA, USA) Gas Chromatograph, model 7890A, equipped with flame ionization detector and mass detector, model 5975C, with polar capillary column HP-FFAP (Free Fatty Acid Phase, Hewlett Packard; $50 \mathrm{~m} \times 0.32 \mathrm{~mm}$ i.d., film thickness $0.52 \mu \mathrm{m}$ ). Temperature program for HPFFAP column was: $70^{\circ} \mathrm{C}$ isothermal for $4 \mathrm{~min}$, than increased to $180{ }^{\circ} \mathrm{C}$ at a rate of $4{ }^{\circ} \mathrm{C} \min ^{-1}$ and subsequently held isothermal for $15 \mathrm{~min}$. Carrier gas was helium at flow rate $1 \mathrm{~mL} /$ min, injector temperature was $250^{\circ} \mathrm{C}$, injected volume $1 \mu \mathrm{L}$;

This is an open access journal, and articles are distributed under the terms of the Creative Commons Attribution-NonCommercial-ShareAlike 4.0 (CC BY-NC-SA 4.0) International License which allows readers to freely read, download, copy, distribute, print, search, or link to the full texts of its articles and to use them for any other lawful non-commercial purpose as long as the original source is duly acknowledged. 
split ratio of 1:50; FID detector temperature was $300^{\circ} \mathrm{C}$. Mass spectrometer ionization voltage was $70 \mathrm{eV}$, mass scan range: 30-300 mass units and ion source temperature was $280{ }^{\circ} \mathrm{C}$.

Compounds identification and quantification: Identification of volatile compounds were based on comparison of compounds mass spectra with databases (Wiley 275 libraryWiley, New York, NY, USA) and comparison of their retention indices (relative to series of $n$-alkanes $\mathrm{C}_{9}-\mathrm{C}_{40}$ ), with internal database retention indices and literature retention indices using NIST2002 (National Institute of Standards and Technology, Gaithersburg, MD, USA) [5,6]. The internal database of compounds was created during previous analyses from authentic compounds obtained commercially and from more than thousand volatile oils obtained during our previous studies. The percentages of components were calculated as mean values from the GC and GC-MS peak areas.

Acetylcholinesterase inhibition potential of volatile oil: Acetylcholinesterase (AChE) inhibition potential of Arbutus unedo volatile oil isolated from leaves was carried out by a slightly modified Ellman method [7]. A run consisted of 180 $\mu \mathrm{L}$ of phosphate buffer (0.1 M, pH 8), $10 \mu \mathrm{L}$ of DTNB (at a final concentration of $0.3 \mathrm{mM}$ prepared in $0.1 \mathrm{M}$ phosphate buffer $\mathrm{pH} 7$ with $0.12 \mathrm{M}$ sodium bicarbonate added for stability), $10 \mu \mathrm{L}$ of sample solution (dissolved in $80 \% \mathrm{EtOH}$ ) and $10 \mu \mathrm{L}$ of $\mathrm{AChE} / \mathrm{BChE}$ solution (with final concentration $0.03 \mathrm{U} / \mathrm{mL}$ ). Reactants were mixed in a 96-well plate wells and reaction was initiated by adding $10 \mu \mathrm{L}$ of acetylthiocholine iodide iodide (ATChI), to reach a final concentration of $0.5 \mathrm{mM}$. As a negative control, $80 \% \mathrm{EtOH}$ was used instead of sample solution. Non-enzymatic hydrolysis was also monitored by measurement of two blank runs for each run. All spectrophotometric measurements were performed at $405 \mathrm{~nm}$ and at room temperature for 6 min periods. The results are expressed as percentage inhibition of enzyme activity. The experiment was performed in triplicate and the results were expressed as mean.

\section{RESULTS AND DISCUSSION}

The yield of $0.06 \%$ was obtained from Arbutus unedo volatile oil isolated from fresh leaves. Sixty volatile oil compounds, representing $93.7 \%$ of total oil, were identified (Table-1). The principal oil compounds were nonterpene compounds, with (E)-2-decenal (14.1\%), nonanal $(9.5 \%)$, nonanoic acid $(8.1 \%)$ and octanol (5.2\%) as main compounds. Terpene compounds were identified in lower quantity, with linalool (4.4 $\%)$ and $\alpha$-terpineol (2.9\%) as main ones. Other volatile oil compounds were identified in lower quantity.

This is the first record about chemical composition of volatile oil from leaves of $A$. unedo of Croatian origin. Previously, the volatile oil composition of $A$. unedo leaves from Algeria and Turkey were performed $[3,4]$. The chemical composition of volatile oil from leaves of $A$. unedo from Algeria oil was characterized by a high content of pamitic acid (35.2\%) and linoleic acid (18.8\%) and the presence of heavy aliphatic hydrocarbons. According to authors this oil belongs to palmitic acid, linoleic acid and $p$-cresol, 2,6-di-tert-butyl-chemotype of $A$. unedo oil. The principal components of Turkish oil were $(E)$ 2-decenal $(12.0 \%)$, $\alpha$-terpineol $(8.8 \%)$, hexadecanoic acid $(5.1 \%)$ and $(E)$-2-undecenal $(4.8 \%)$. The results of this study
TABLE-1

CHEMICAL COMPOSITION OF Arbutus unedo VOLATILE OIL

\begin{tabular}{|c|c|c|}
\hline Identified compound & $\mathrm{KI}$ & $\%$ \\
\hline$\alpha$-Pinene & 1045 & 0.1 \\
\hline Ethyl butanoate & 1047 & 1.2 \\
\hline Ethyl 2-methylbutanoate & 1053 & 0.7 \\
\hline Ethyl 3-methylbutanoate & 1064 & 0.5 \\
\hline Hexanal & 1092 & 0.7 \\
\hline Undecane & 1100 & 0.8 \\
\hline 2-Pentanol & 1112 & 0.4 \\
\hline p-Xylene & 1140 & 0.5 \\
\hline Ethyl 2-butenoate* & 1159 & 2.9 \\
\hline 4-Methyl-3-penten-2-one & 1165 & 0.4 \\
\hline Heptanal & 1167 & 0.9 \\
\hline Isopentyl alcohol & 1174 & 0.4 \\
\hline Limonene & 1240 & 1.2 \\
\hline Octanal & 1289 & 1.6 \\
\hline cis-3-Hexenyl acetate* & 1305 & 0.9 \\
\hline 2,2,6-Trimethyl cyclohexanone & 1310 & 0.8 \\
\hline 2-Heptenal* & 1316 & 0.5 \\
\hline Hexanol & 1320 & 0.4 \\
\hline 3-Hexen-1-ol* & 1400 & 0.6 \\
\hline Nonanal & 1402 & 9.5 \\
\hline 3,5,5-Trimethyl-3-cyclohexene-1-one & 1410 & 1.4 \\
\hline 2-Octenal* & 1429 & 0.6 \\
\hline trans-Linalool oxyde & 1450 & 0.4 \\
\hline Etanoic acid & 1462 & 1.8 \\
\hline Heptanol & 1467 & 0.3 \\
\hline 3-Hexenyl-2-methylbutanoate* & 1480 & 0.9 \\
\hline Nonane, 1,1-diethoxy & 1515 & 0.7 \\
\hline Propanoic acid & 1547 & 0.7 \\
\hline Vitispirane & 1551 & 1.4 \\
\hline Linalool & 1557 & 4.4 \\
\hline 3,4-Dimethyl 2-pentene* & 1561 & 0.6 \\
\hline Octanol & 1564 & 5.2 \\
\hline 2-Undecanone & 1579 & 1.0 \\
\hline$\beta$-Cyclocitral & 1635 & 1.5 \\
\hline (E)-2-Decenal & 1647 & 14.1 \\
\hline 3-Methyl butanoic acid & 1651 & 0.6 \\
\hline Methyl benzoate & 1653 & 2.4 \\
\hline$\alpha$-Terpineol & 1701 & 2.9 \\
\hline 4-Ketoisophorone & 1705 & 0.4 \\
\hline Verbenone & 1710 & 0.5 \\
\hline 2-Undecanal & 1736 & 2.0 \\
\hline Methyl salicylate & 1773 & 1.1 \\
\hline Nerol & 1808 & 0.5 \\
\hline 2-Tridecanon & 1812 & 1.3 \\
\hline$(E, E)$-2,4-Decadienal & 1814 & 0.2 \\
\hline Ethyl salicylate & 1820 & 0.4 \\
\hline (E)- $\beta$-Damascenone & 1826 & 0.6 \\
\hline Hexanoic acid & 1849 & 0.7 \\
\hline Geraniol & 1859 & 1.4 \\
\hline p-Cymen-8-ol & 1862 & 0.2 \\
\hline Geranyl acetone & 1867 & 0.4 \\
\hline Benzyl alcohol & 1883 & 0.5 \\
\hline Ethyl hydrocinnamate & 1889 & 0.5 \\
\hline Heptanoic acid & 1944 & 1.0 \\
\hline$\beta$-Ionone & 1948 & 1.2 \\
\hline Nerolidol & 2018 & 0.6 \\
\hline Octanoic acid & 2050 & 2.4 \\
\hline 3-Hexenyl benzoate* & 2127 & 1.6 \\
\hline Ethyl cinnamate* & 2129 & 2.2 \\
\hline Nonanoic acid & 2150 & 8.1 \\
\hline Total & & 93.7 \\
\hline
\end{tabular}

$\mathrm{KI}=$ Retention indices relative to $\mathrm{C}_{9}$ - $\mathrm{C}_{40} n$-alkanes on polar HP-FFAP column, *Correct isomer is not identified. 
showed that the Croatian $A$. unedo volatile oil isolated from leaves is more similar to Turkish oil than to Algerian oil.

Acetylcholinesterase inhibition activity of $A$. unedo volatile oil was also tested. This is the first record about $\mathrm{AChE}$ inhibition activity of this oil. AChE inhibition activity was tested by Ellman method [7]. Results showed low to moderate AChE activity of tested oil (48.5\%) for tested concentration of $1 \mathrm{mg} / \mathrm{mL}(0.045$ $\mathrm{mg} / \mathrm{mL}$ in reaction system) (Table-2). For comparison, eserine as referent compound showed $92.2 \%$ inhibition of AChE for tested concentration of $0.1 \mathrm{mg} / \mathrm{mL}(4.5 \mu \mathrm{g} / \mathrm{mL}$ in reaction system). Among volatile compounds identified as components of tested oil, several compounds were previously tested on AChE inhibition. Among them, $\beta$-ionone, verbenone, geraniol and $\alpha$-terpineol showed good AChE inhibition potential [813]. These compounds or synergism of these compounds are probably responsible for low to moderate, but noticeable, AChE inhibition activity of tested oil.

\begin{tabular}{lc}
\multicolumn{1}{c}{ TABLE-2 } \\
\multicolumn{1}{c}{ ACETYLCHOLINESTERASE INHIBITION } \\
POTENTIAL OF Arbutus unedo VOLATILE OIL \\
\hline \multicolumn{1}{c}{ AChE inhibition $(\%)$} \\
\hline Volatile oil $^{\mathrm{a}}$ & 48.5 \\
Eserine $^{\mathrm{b}}$ & 92.9 \\
\hline${ }^{\mathrm{a}}$ Tested concentration was $1 \mathrm{mg} / \mathrm{mL}(0.045 \mathrm{mg} / \mathrm{mL}$ in reaction system); \\
${ }^{\mathrm{b}}$ Tested concentration was $0.1 \mathrm{mg} / \mathrm{mL}(4.5 \mu \mathrm{g} / \mathrm{mL}$ in reaction system $)$
\end{tabular}

\section{Conclusion}

The volatile oil from leaves of Arbutus unedo from Croatia was subjected to chemical composition and acetylcholinesterase inhibition activity. The tested volatile oil was dominated by nonterpene compounds, with $(E)$-2-decenal (14.1\%), nonanal $(9.5 \%)$, nonanoic acid $(8.1 \%)$ and octanol $(5.2 \%)$ as main compounds. Terpene compounds were identified in lower quantity, with linalool $(4.4 \%)$ and $\alpha$-terpineol $(2.9 \%)$ as main ones. Acetylcholinesterase inhibition activity of tested volatile oil showed low to moderate AChE inhibition activity (48.5\%) for tested concentration of $1 \mathrm{mg} / \mathrm{mL}$.

\section{ACKNOWLEDGEMENTS}

The study was financially supported by Croatian Science Foundation under the project IP-2014-09-6897. The authors also acknowledge the botanical identification of the plant material by Dr. Mirko Ruscic, Associate Prof., Faculty of Science, Department of Biology, University of Split, Croatia.

\section{CONFLICT OF INTEREST}

The authors declare that there is no conflict of interests regarding the publication of this article.

\section{REFERENCES}

1. S. Morgado, M. Morgado, A.I. Placido, F. Roque and A.P. Duarte, $J$. Ethnopharmacol., 225, 90 (2018); https://doi.org/10.1016/j.jep.2018.07.004.

2. I. Oliveira, P. Baptista, A. Bento and J.A. Pereira, J. Food Nutr. Res., 50, 73 (2011).

3. R. Bessah and E.-H. Benyoussef, J. Essent. Oil Bear. Plants, 15, 678 (2012); https://doi.org/10.1080/0972060X.2012.10644105

4. B. Kivcak, T. Mert, B. Demirci and K.H.C. Baser, Chem. Nat. Compd., 37, 445 (2001); https://doi.org/10.1023/A:1014419309885.

5. R.P. Adams, Identification of Essential Oil Components by Gas Chromatography/Mass Spectrometry, Allured Publ Corp Carol Stream: IL, USA, edn 4 (2005).

6. P.J. Linstrom and W.G. Mallard, NIST Chemistry WebBook, NIST Standard Reference Database, Number 69 (2014).

7. G.L. Ellman, K.D. Courtney, V. Andres and R.M. Featherstone, Biochem. Pharmacol., 88, 7 (1961).

8. N.S.L. Perry, P.J. Houghton, A. Theobald, P. Jenner and E.K. Perry, J. Pharm. Pharmacol., 52, 895 (2000); https://doi.org/10.1211/0022357001774598.

9. M.D. López, F.J. Campoy, M.J. Pascual-Villalobos, E. Muñoz-Delgado and C.J. Vidal, Chem. Biol. Interact., 229, 36 (2015); https://doi.org/10.1016/j.cbi.2015.01.006

10. S. Dohi, M. Terasaki and M. Makino, J. Agric. Food Chem., 57, 4313 (2009); https://doi.org/10.1021/jf804013j.

11. A.T. Mata, C. Proença, A.R. Ferreira, M.L.M. Serralheiro, J.M.F. Nogueira and M.E.M. Araújo, Food Chem., 103, 778 (2007); https://doi.org/10.1016/j.foodchem.2006.09.017.

12. M. Miyazawa, A. Kakiuchi, H. Watanabe and H. Kameoka, Nat. Prod. Lett., 12, 131 (1998); https://doi.org/10.1080/10575639808048281.

13. F. Burcul, I. Blazevic, M. Radan and O. Politeo, Curr. Med. Chem., 25, (2018) (in press); https://doi.org/10.2174/0929867325666180330092607. 